\title{
Analýza výzkumů vizuálií v učebnicích na př́íkladu učebnic s geografickým obsahem ${ }^{1}$
}

\author{
Petr Trahorsch, ${ }^{a}$ Jan D. Bláha, ${ }^{\mathrm{b}}$ Tomáš Janko ${ }^{\mathrm{c}}$ \\ ${ }^{a}$ Univerzita J. E. Purkyně v Ústí nad Labem, Pedagogická fakulta \\ ${ }^{\mathrm{b}}$ Univerzita J. E. Purkyně v Ústí nad Labem, Př́rodovědecká fakulta \\ ${ }^{\mathrm{c}}$ Masarykova univerzita, Pedagogická fakulta
}

Redakci zasláno 11. 10. 2017 / upravená verze obdržena 8. 2. 2018 /

k uveřejnění přijato 8. 2. 2018

\begin{abstract}
Abstrakt: Článek je přehledovou studií, jejímž cílem je vymezit a kriticky zhodnotit metodologické přístupy výzkumů vizuálií v učebnicích s geografickým obsahem. Dalším cílem této studie je shrnout hlavní závěry vědeckých prací a naznačit perspektivy budoucího výzkumu. V rámci odborných prací je zřetelná terminologická nejednotnost označení pro netextovou - ilustrační složku učebnic. Celkem bylo analyzováno 92 studií bez časové a územní specifikace v českém a anglickém jazyce, které byly vyhledány $\mathrm{v}$ multioborových časopiseckých fulltextových databázích (konkrétně EBSCO, WoS, SCOPUS, ERIC, ProQuest a Geobibline) pomocí kombinace českých klíčových slov a jejich anglických ekvivalentů. Samotná analýza výzkumů ukázala, že ve výzkumech převládá expertní hodnocení využívající převážně kvantitativně orientované metody, mezi něž patři především kvantitativní obsahová analýza vizuálií; v rámci kvantitativně orientovaného uživatelského hodnocení má klíčový význam metoda dotazníku a didaktického testu. Dále bylo zjištěno nerovnoměrné zastoupení výzkumů vizuálií např́ič stupni škol; opomíjenou oblastí výzkumu jsou učebnice pro věkové období ISCED 1. V rámci učebnic geografie mají klíčové zastoupení fotografie; ačkoliv mapy jsou jedněmi z typických geografických vizuálií, jejich podíl na celkovém počtu vizuálií v učebnicích je podle výsledků analyzovaných výzkumů relativně nízký.
\end{abstract}

Klíčová slova: vizuálie, učebnice zeměpisu, učebnice vlastivědy, učebnice s geografickým obsahem, přehledová studie

Význam vizuální informace $\mathrm{v}$ současné době roste. Jednou $\mathrm{z}$ příčin je růst množství dat a $\mathrm{z}$ nich vyplývajících informací (tzv. informační exploze), které musí být ostatním lidem prezentovány $\mathrm{v}$ přehledné, názorné

1 Výzkum, v rámci něhož vznikl tento text, byl podpořen SGS UJEP (projekt č. UJEP-SGS-2017-43-009-3 Vizuálie v učebnicích zeměpisu a vlastivědy a jejich vliv na vznik miskonсерсî) a GA ČR (projekt č. 16-01003S Vizuální geografická informace a její role v geografickém vzdělávání). 
a především redukované formě (Spousta, 2007). Důležitou úlohu hrají vizuálie zejména v různých médiích (noviny, internet, televize, mobilní aplikace), které pro prezentaci využívají v mnohem větší míře fotografií, map, schémat atd. Výhodou je především to, že čtenář získá během krátké chvíle relativně velké množství informací, které by v textu náročně hledal (efektivita mediální komunikace). Problematická však může být kvalita vizuálií, která při nevhodně zvolené koncepci může vizualizovaný jev či proces zkreslovat nebo být dokonce příčinou vzniku miskoncepcí.

Ve školní výuce jsou využívány rozmanité druhy vizuálií, které jsou obsaženy v různých didaktických prostředcích. Jedná se například o atlasy, nástěnné mapy, počítačové programy nebo animace. Pravděpodobně nejdůležitější materiální didaktický prostředek, tedy učebnice, obsahuje taktéž velké množství vizuálií, jejichž počet se v průběhu posledního století zásadně zvýšil, což jistě souvisí s lepšími technologickými možnostmi tisku. Jedním $\mathrm{z}$ vyučovacích předmětů, $\mathrm{v}$ němž se $\mathrm{v}$ učebnicích tradičně využívá vizuální informace, je geografie. Ta je do národního kurikula začleňována odlišně; např́́klad v Česku je typická dichotomie: na prvním stupni základních škol je zpravidla vyučovacím předmětem vlastivěda, na druhém stupni zeměpis ( $\mathrm{v}$ některých př́padech geografie). $\mathrm{V}$ jiných státech může být geografie implementována do kurikula jiným způsobem, např. do obsahu učiva př́irodních či společenskovědních předmětů. Díky využití vizuální informace na všech stupních vzdělávání je geografie označována jako vizuální vědní obor (např. Wright, 1979). Tento fakt souvisí s charakterem geografie jako oboru studujícího primárně vztahy a souvislosti v prostoru, které jsou vizualizovány ve formě mapy jako jednoho ze základních vyjadřovacích prostředků prostorové informace. Dále je pro tento obor typické větší množství dat z povahově odlišných disciplín integrujících se v geografii (Gregory et al., 2009). Specifikem oproti jiným vyučovacím předmětům je jistě její pozice v kurikulárních dokumentech Česka na pomezí přírodní a společenskovědní vzdělávací oblasti, a tím i požadavek na komplexní uchopení učiva a taktéž upozornění na vztahy mezi př́rodou a společností (Řezníčková, 2014). Tyto charakteristiky vyžadují názorné a zároveň vizuální pojetí komunikace.

Jak uvádí Průcha (2008), počet výzkumů učebnic v Česku v posledních letech roste. Problémem je ovšem nerespektování významu netextové (ilustrační) složky učebnic (na rozdíl od textové); klíčové postavení této složky dosvědčuje většina výzkumů především z pedagogické a obrazové psychologie, nebot' 
jejich výsledky potvrzují efektivnější učení z kombinace textu a vizuálií než ze samotného textu (např. Lewalter, 2003); na druhé straně v některých empirických studiích nebyl prokázán pozitivní vliv vizuálií na učení, nebo se míra efektivity učení u studentů s odlišnými studijními předpoklady značně lišila, proto je k užití vizuální informace ve výuce nutné přistupovat kriticky (Peeck, 1993). Ani jeden z nejpoužívanějších nástrojů k hodnocení učebnic - koeficient didaktické vybavenosti - nezohledňuje hlubší pohled na vizuálie jako zdroj informací, které žák využívá při učení. V posledních letech se situace poněkud zlepšuje, avšak chybí propracovanější metodika hodnocení kvality vizuálií. Problémem je neexistující přehled metodologických př́ístupů k hodnocení vizuálií v učebnicích geografie a jejich kritické zhodnocení, stejně jako přehled nejdůležitějších výsledků, který by odhaloval potenciál budoucích výzkumů.

Cílem této přehledové studie je na základě analýzy výzkumů vizuálií v učebnicích s geografickým obsahem kategorizovat metodologické př́ístupy podle společných znaků s kritickým zhodnocením jejich výhod a nevýhod a jejich dalšího potenciálu. Mezi hlavní kritéria analýzy patřil věk uživatelů, pro které jsou učebnice (vizuálie) určeny či kteří se na jejich hodnocení podíleli, dále typologie výzkumů $\mathrm{z}$ hlediska participace uživatelů a v neposlední řadě metodologická orientace hodnocení vizuálií. Právě tato kritéria mohou při výzkumech vizuálií poskytnout zcela rozdílný charakter výsledků, čímž se výsledky studií mohou vhodně doplňovat. Dalším kritériem pro třídění studií byla empirická metoda použitá v rámci analyzovaných studií, což umožňuje zjistit škálu možných metod výzkumu tohoto strukturního komponentu učebnice. Druhým cílem této studie je shrnout hlavní závěry vědeckých prací a naznačit perspektivy budoucího výzkumu.

\section{Terminologické vymezení pojmů}

Před analýzou výzkumných studií bylo nutné definovat a vymezit pojmy vztahující se k netextové (ilustrační) složce učebnic. Zde nastal prvotní problém, protože řada prací operuje s určitým pojmem bez zdůvodnění dalších souvislostí. $\mathrm{V}$ odborné literatuře se užívá několik základních pojmů, velmi často duplicitních, jejichž přehled je uveden níže.

Učebnici můžeme charakterizovat jako materiální didaktický prostředek se specificky členěným strukturním systémem, jehož komponenty plní specifické funkce. Pohled na zařazení vizuálií do tohoto systému se různí. Například 
Wahla (1983), který se zabýval př́mo učebnicemi geografie, je řadí do tzv. mimotextové (netextové) složky. Naopak Bednařík (1981) je vymezuje pojmem nevýkladová část učebnice, konkrétně podsložkou obrazový materiál.

V rámci vědeckých studií není jednotné ani pojmenování konkrétních prvků mimotextové složky učebnic. Lze vycházet z obecných teorií komunikace a vizualizace, v nichž je užíváno termínu vizuálie (též vizuália) - (Spousta, 2007). Ty jsou chápány jako předměty nebo jevy a jejich zobrazení nebo znázornění, které člověk vnímá zrakem (Behnke, 2014; Pýchová, 1990; Spousta, 2007). ${ }^{2}$ Typickým rysem tohoto znázornění a zobrazení je subjektivita a nejednoznačnost, čímž může být ovlivněna i efektivita učení (Veriki, 2002). Mezi další pojmy užívané k označení tohoto fenoménu patři nonverbální komponenta (Fedotova, Latun, \& Okuneva, 2014; Janko, 2012), obrazový materiál (Mareš, 1995), vizuální prostředek (Pešková, 2012), grafické zobrazení (Veriki, 2002) a vizuální prvek (Đukičin et al., 2014); tyto pojmy se již vyznačují větší konkrétností. Např́íklad termíny nonverbální komponenta či vizuální prvek se primárně vztahují k učebnicím jako strukturním systémům skládajícím se ze složek a prvků (teorie systémů). Naopak pojem vizuální prostředek odkazuje na dosahování cílů v edukačním procesu. Termíny grafické zobrazení a obrazový materiál jsou užívány především v psychologii a nemusí zahrnovat všechny typy vizuálií užívaných v učebnicích (viz Veriki, 2002). Především v zahraniční literatuře (mimo výše uvedené práce) jsou užívány i pojmy obecnějšího charakteru jako ilustrace (orig. illustrations; Carney \& Levin, 2002), obrázky (orig. pictures; Melbo \& Waterman, 1936) a další (viz např. Slough et al., 2010). Tyto termíny se naopak vyznačují nejednoznačností, která je nedovoluje použít v této studii. Např́klad pojem ilustrace odkazuje na kresbu fenoménu, což u fotografií jako jedněch z často používaných vizuálií v učebnicích není pravda; fotografie lze chápat jako realistické vizuálie.

Podstatou těchto pojmů je netextová (vizuální) prezentace učiva. Ta může být obsažena nejen v materiálních didaktických prostředcích tištěné podoby (např. tištěné učebnice, školní atlasy), ale do budoucna bude jistě růst význam i vizuálií majících digitální podobu; ty mohou vybraný jev nebo proces zobrazovat nejen ve statické, ale i v dynamické formě a lze je potom pojmenovat mnohem obecnějším termínem - didaktický obraz (blíže viz Macek, 1984). Klíčové ovšem je, že vybrané vizualizované fenomény musí uživatel

2 Termín vizuálie jako nosič vizuální informace je použit i v tomto článku. Vyznačuje se relativně velkou univerzálností, proto jej lze aplikovat i ve výzkumu učebnic s geografickým obsahem. Další výhodou použití tohoto pojmu je relativně vysoká míra jeho užívání v anglickém jazyce. 
vnímat a zpracovávat primárně ve vizuální (obrazové) podobě. Teorií, které se zabývají zpracováním verbálních a neverbálních informací, je několik (Mareš, 1995; Veriki, 2002); pravděpodobně nejčastěji se však hovoří o teorii duálního kódování. Ta tvrdí, že jedinec zpracovává informaci dvěma různými kanály, které spolu komunikují, takže pojem má ve výsledku oba aspekty: verbální i neverbální. Efektivita učení, jak dokazují četné výzkumy, je vyšší, protože určitá informace se ukládá do paměti dvakrát v různých formách verbální a neverbální (Paivio, 2014).

Zastřešujícím pojmem pro tuto oblast bádání je vizuální výzkum nebo výzkum založený na obrazovém materiálu (Mareš, 2002). V rámci odborného diskurzu jsou analýzy vizuálií $v$ učebnicích geografie společně s analýzou vizuálií v dalších sdělovacích prostředcích (např. reklama v novinách) součástí tohoto druhu výzkumu.

Prvotní rešerše literatury ukázala, že pro obrazový materiál učebnice (Bednařík, 1981) je užíváno kolem 20 odborných pojmů. Tento fakt zásadně ztěžuje analýzu výzkumů, protože nejednotnost pojmenování stejného fenoménu ovlivňuje výběr klíčových slov. Autoři prací napříč obory (pedagogická psychologie, oborové didaktiky, obecná didaktika) volí různé pojmy pro tentýž jev. Ve většině případů ani nejsou uvedeny příčiny a souvislosti užívání konkrétního pojmu, což je problematické z důvodu potenciálního srovnání výsledků výzkumů. Nedostatečné terminologické ukotvení problému může ukazovat i na menší tradici výzkumu vizuálií v učebnicích, což lze doložit neexistencí plně standardizovaného metodického nástroje. ${ }^{3}$ Tím se vizuálie zásadně odlišují od textové složky učebnice, pro kterou již bylo několik syntetických ukazatelů konstruováno a ověřeno (Průcha, 1998).

\section{Metodika analýzy}

Výzkumné studie byly vyhledávány pomocí multioborových časopiseckých fulltextových databází; konkrétně se jednalo o databáze EBSCO, Web of Science, SCOPUS, ERIC, ProQuest a Geobibline ${ }^{4}$. Autoři se domnívají, že

Existuje několik výjimek, kdy se autoři snažili své výzkumné nástroje alespoň částečně standardizovat. V Česku se jedná například o kategoriální systémy Janka (2012) nebo Peškové (2012); v zahraniční literatuře např. o systém Slougha a kol. (2010), kteří svůj metodický nástroj pojmenovali Grafický analytický protokol (GAP).

4 Geobibline je česká geografická bibliografická databáze, kterou spravuje Univerzita Karlova (Praha), Masarykova univerzita (Brno) a Univerzita J. E. Purkyně v Ústí nad Labem. 
zvolené databáze poskytují širokou škálu kvalitních odborných studií a pokrývají výzkumné pole řešeného problému. Podmínkou bylo, aby výzkumné studie byly ve fulltextové verzi; k dohledání plných textů byla ještě využita další webová rozhraní, jako například ResearchGate či Google Scholar (tyto webové stránky ale nebyly primárně určeny k vyhledávání studií). Přístup do databází byl zajištěn přes Národní knihovnu ČR a UJEP v Ústí nad Labem, což mohlo ovlivnit dostupnost některých odborných článků. Při výběru studií nebylo uplatněno časové omezení, tj. rozmezí let, v rámci něhož autoři studie vyhledávali. Důvodem je především relativně nízký počet výzkumů vizuálií v učebnicích, který by po definici sledovaného časového období ještě klesl; dalším důvodem je potenciální možnost srovnání výsledků starších a novějších studií. Studie nebyly územně limitovány. Bylo využito hledání pomocí klíčových slov v češtině i angličtině a jejich kombinací; vždy bylo provedeno vyhledávání pomocí jednoslovných a dvouslovných klíčových slov, tzv. „každý s každým“. Jednalo se o tyto pojmy: vizuálie, nonverbální prvek, učebnice zeměpisu, učebnice vlastivědy, ilustrační materiál, geografie, vlastivěda, mapy, grafy, fotografie, obrázky, analýza učebnice, přírodovědné učebnice. Pozornost byla zaměřena na výskyt hledaných pojmů v názvu článku, klíčových slovech a abstraktu. Další studie byly dohledány na základě bibliografie analyzovaných výzkumných studií (musely ovšem splňovat níže uvedená kritéria). Na základě tohoto postupu bylo vyhledáno celkem156 studií, které musely být dále analyzovány a utříděny. $V$ prvé řadě byly vybrány pouze recenzované studie, které byly autorům dostupné v plnotextové podobě v českém nebo anglickém jazyce (celkem 132 studií). $V$ dalším kroku byly vybrány i ty studie, které se zabývaly vizuáliemi znázorňujícími geografická témata (viz vymezení geografie $v$ úvodu); po této fázi selekce byl analyzován název a abstrakt u 109 studií. Po analýze názvu studie a abstraktu autoři přistoupili k další selekci z důvodu nižší relevantnosti dohledaných studií (v této fázi celkem 101 studií). Základní kritéria pro vyřazení dohledaných studií byla tato:

- nejasně definovaný vzorek výzkumu (učebnice, uživatelé), neformulovaný nebo nejasně formulovaný cíl studie;

- zprávy z předvýzkumu; práce, které byly v době hledání studií ještě rozpracovány, protože neposkytují kompletní výsledky hodnocení vizuálií a zároveň existuje pravděpodobnost, že metodický postup bude v dalších fázích výzkumu upravován; 
- studie, které se vizuáliemi v učebnicích s geografickým obsahem zabývaly velmi okrajově (např. primárně byl hodnocen text v učebnicích a ve studii byl pouze stručně zmíněn obsah vizuálií bez jejich další specifikace či analýzy).

Studie odpovídající těmto kritériím, byly z analýzy vyřazeny. Součástí podrobné analýzy tak bylo ve finální fázi celkem 92 studií, mezi něž patřily odborné články (63\%), knihy (3\%), kapitoly v monografiích (3\%), diplomové a disertační práce (23\%), př́íspěvky ve sbornících a příspěvky z konferencí (8\%). Celkem $36 \%$ analyzovaných studií je české provenience, $64 \%$ studií pochází ze zahraničí.

Analýza studií probíhala dle několika kritérií, přičemž každé kritérium mělo svá metodologická specifika, na která je nutno upozornit. Pro analýzu studií z hlediska věku uživatelů bylo užito standardizované metodiky stupňů škol UNESCO (UNESCO, Institute for Statistics, 2012); pokud v rámci jedné studie byl výzkum realizován u více věkových kategorií, jsou ve výsledcích započítány všechny věkové kategorie. Dalším kritériem byla participace uživatelů na výzkumu vizuálií, které lze podobně jako v jiných odborných disciplínách kategorizovat na expertní, uživatelské a kombinované (Bláha, 2010). Dalším kritériem byla metodologická orientace studií, které lze rozdělit na kvantitativně a kvalitativně orientované a na tzv. kvalimetrii (Hendl, 2012). Tyto kategorie výzkumů se vyznačují odlišným přístupem výzkumníka, interpretací dat, výběrem výzkumného vzorku atd. Dalším kritériem byla použitá empirická metoda hodnocení vizuálií; pokud bylo ve výzkumu užito více metod, tak jsou ve výsledcích započítány všechny použité metody (počet metod tedy plně nekoresponduje s počtem analyzovaných studií).

\section{$3 \quad$ Výsledky a jejich diskuze}

Analýza studií podle stanovených kritérií (např. věk, participace uživatelů, použitá empirická metoda atd.) vždy podléhá cíli výzkumu. Stanovit kategorie cílů studií je velmi obtížné (viz např. Řezníčková, 2014), protože jednotlivé cíle se navzájem kombinují a prolínají; celkově by tato kategorizace byla nepřehledná. Přesto se autoři snažili stanovit alespoň základní cíle výzkumů vizuálií $\mathrm{v}$ učebnicích s geografickým obsahem, které následně ovlivňují výběr rozsahu věku uživatelů, míru participace uživatelů na hodnocení a samozřejmě volbu metodologické orientace a konkrétních metod (viz obrázek 1), o kterých je pojednáno v kapitolách 3.1-3.4. 

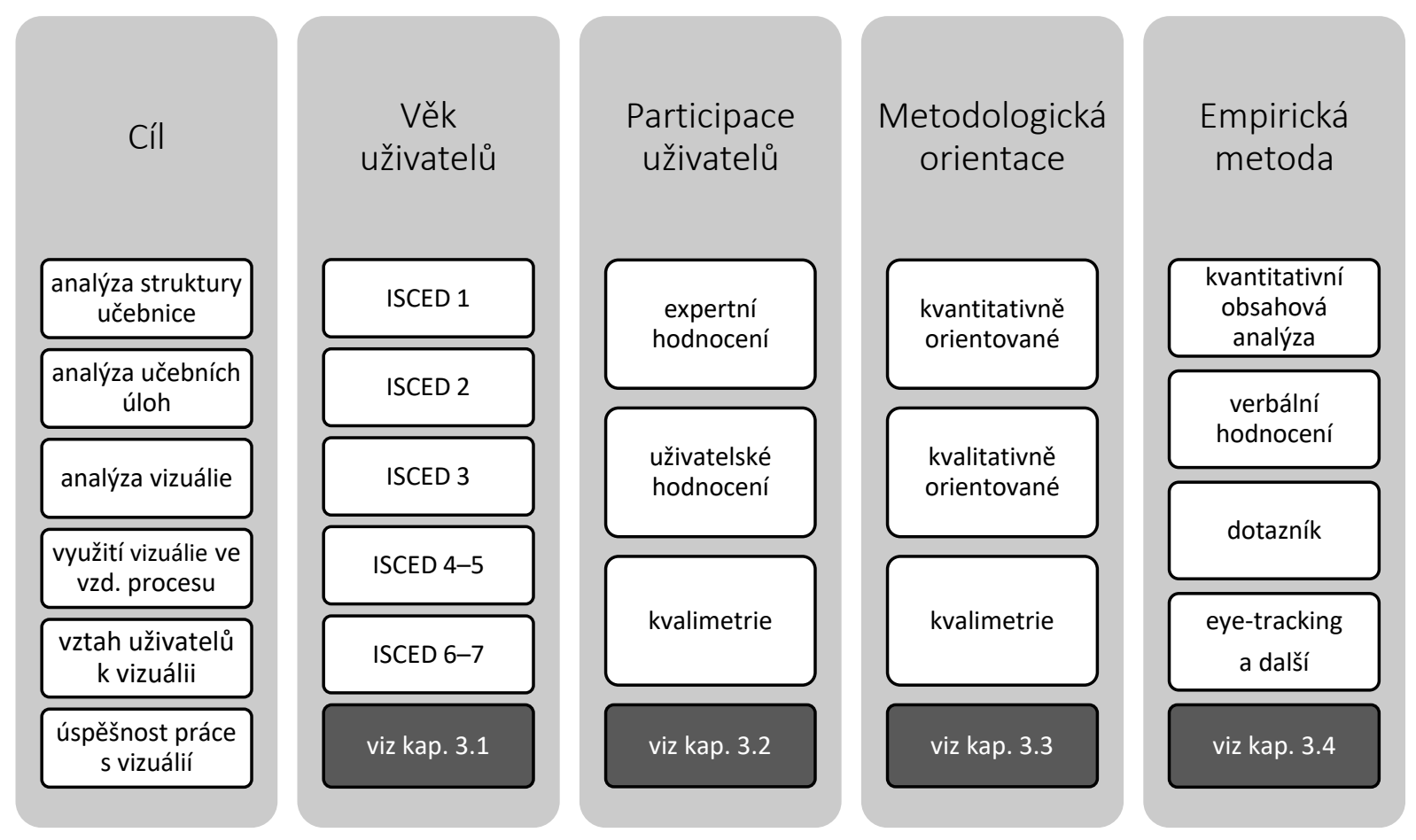

Obrázek 1. Základní možnosti volby metodického designu výzkumu vizuálií $\mathrm{v}$ učebnicích v závislosti na cíli studie.

\subsection{Výzkumy vizuálií v učebnicích s geografickým obsahem z hlediska věku uživatelů}

Nejvíce studií se zabývá hodnocením vizuálií v učebnicích pro nižší sekundární školy odborníky nebo hodnocením žáků (resp. učitelů) z tohoto stupně školy (tj. ISCED 2). Poněkud méně prací se zabývá vizuáliemi pro vyšší sekundární stupeň škol (ISCED 3). Tyto dvě věkové kategorie tvoří klíčový podíl na výzkumech vizuálií (celkem $75 \%$ ), což může souviset s výskytem geografie jako samostatného učebního předmětu (předmět není integrován do kurikula jiných předmětů). Nízký je počet výzkumů vizuálií pro primární stupeň škol; tento fakt může souviset s větší integrací učiva pro mladší žáky. To klade větší požadavky na odbornost hodnotitelů, resp. výzkumníků. Nízký je i počet výzkumů učebnic pro vysoké školy (ISCED 6 a 7), který tvoří necelých $6 \%$. Př́ičinou je pravděpodobně relativně nízký počet uživatelů (studentů), čímž jistě klesá i spektrum využívaných učebnic. V neposlední řadě je nutné zmínit fakt, že učebnice pro nižší věkové stupně ovlivňují mnohem vyšší počet jedinců, a tak mohou být častěji vybírány jako předmět výzkumu. 
Celkové výsledky analýzy výzkumů z hlediska věkové kategorie uživatelů ukazuje tabulka 1.

Tabulka 1

Výzkumy vizuálií $v$ učebnicích $s$ geografickým obsahem $z$ hlediska věku uživatelů

\begin{tabular}{cc}
\hline Věková kategorie & Počet (abs.) \\
\hline ISCED 1 & 19 \\
ISCED 2 & 55 \\
ISCED 3 & 37 \\
ISCED 6 a 7 & 7 \\
nerozlišeno & 4 \\
\hline
\end{tabular}

\subsection{Výzkumy vizuálií z hlediska participace uživatelů}

Expertní hodnocení provádí odborníci na danou problematiku, nikoliv samotní uživatelé. Výzkumník se nezajímá o stanovisko uživatele (tedy žáka nebo učitele). Cílem je zjistit, zda vizuální prvky odpovídají svému účelu, cíli, přiměřenosti věku žáků atd. Důraz je kladen na odbornost hodnocení ve smyslu terminologie, didaktických pravidel, zákonitostí učení atd. (Mareš, 2002; Průcha, 1998). V rámci analýzy výzkumů bylo zjištěno, že toto hodnocení silně převládá (celkem $72 \%$ analyzovaných výzkumů vizuálií prováděli pouze experti bez participace uživatelů). Pro výzkumníky je jistě jednodušší provést analýzu učebnic na svém pracovišti v pohodlí kanceláře než provádět výběr výzkumného souboru, oslovovat ředitele škol a samotné učitele a žádat je o svolení k výzkumu na jejich škole. Roli zde hrají i nižší finanční náklady na výzkum.

Uživatelské hodnocení je zaměřené na žáky a/nebo učitele. $V$ tomto směru výzkumu vizuálií naopak výzkumníka zajímá názor samotného uživatele. Tímto přístupem lze získat cenné informace od subjektů výchovně-vzdělávacího procesu, které by měly být zpětnou vazbou pro autory a nakladatele učebnic, protože právě žáci a učitelé tyto didaktické prostředky ve výuce aktivně používají. Odborníci mohou pro zjištování názorů na kvalitu vizuálií využít řadu výzkumných metod; mezi nejčastěji používané patří rozhovor, dotazník, škálování, mentální mapování, didaktický test, pozorování a další (viz dále). Důležitá je ovšem pečlivá př́íprava otázek, které se předem posuzují, testují a vyhodnocují. Pokud jsou otázky položeny uživatelům nevhodně, 
může z jejich strany dojít k zavádějící výsledkům, které snižují důvěryhodnost celého šetření (Voženílek \& Kaňok et al., 2011). Zastoupení tohoto směru ve výzkumu vizuálií $\mathrm{v}$ učebnicích s geografickým obsahem je podstatně nižší než četnost expertního hodnocení (necelých $22 \%$ z celkového počtu analyzovaných výzkumů). Příčinou může být náročnost tvorby metodického nástroje (např. výše uvedeného dotazníku či didaktického testu), organizační a finanční náročnost výzkumu (výběr respondentů, tisk dotazníků, cesta za účastníky rozhovorů), ale i neochota výzkumníků provádět terénní (nebo také praktický) výzkum se samotnými uživateli. Relativně nejvyšší oblibu má tento směr výzkumu ve věkové kategorii ISCED 6 a 7, v rámci níž tvoří 50 \% všech výzkumů. Výsledek pravděpodobně souvisí s dobrými vyjadřovacími schopnostmi respondentů v porovnání se žáky nižších stupňů škol, čímž jsou kladeny nižší požadavky na přiměřenost a vhodnost výběru výzkumného nástroje. Dalším důvodem může být relativně snadná dostupnost výzkumného vzorku pro výzkumníka; ten v př́ípadě univerzitního prostředí nepotřebuje oslovovat ředitele nebo učitele škol určených pro mladší věkové kategorie a může přímo sám oslovit respondenty $\mathrm{v}$ rámci jejich studia. Problematická je ale následně statistická zobecnitelnost závěrů $\mathrm{v}$ případě kvantitativního šetření.

Kombinované hodnocení spojuje předchozí dva směry výzkumu. Vizuálie jsou hodnoceny jak odborníkem na danou problematiku, tak samotným uživatelem. Daný př́stup poskytuje komplexní evaluaci kvality vizuálií, jelikož je ve výzkumu zohledněno více faktorů, které mají vliv na konečný charakter učebnice. Problematická je ale finanční, organizační a časová náročnost výzkumu. Tento směr se ve výzkumech vizuálních prvků učebnic s geografickým obsahem uplatňuje ve významné menšině $(6,5 \% \mathrm{z}$ analyzovaných výzkumů), což může souviset především se zaneprázdněností akademiků (odborníků) znemožňující provádět rozsáhlejší výzkumy, s podfinancováním rozsáhlých výzkumných projektů učebnic, stejně jako s nesystematičností a horším postavením problematiky výzkumu učebnic v tuzemsku oproti zahraničí (Průcha, 2006). Frekvenci používání těchto př́ístupů v evaluaci vizuálií, včetně zastoupení kvantitativně a kvalitativně orientovaných výzkumů v učebnicích geografie, ukazuje obrázek 2.

Srovnání výhod a nevýhod jednotlivých směrů hodnocení z hlediska participace uživatelů je uveden $v$ Tabulce 2 . Do kategorizace prezentované v této kapitole zasahuje i předmět hodnocení. Experti mohou například vyjadřovat 
názory na kvalitu vizuálií i expertně posuzovat kritéria hodnocení (např. metodou delphi); naopak uživatelé mohou hodnotit vizuálie těmi samými výzkumnými prostředky, avšak každý z nich bude upřednostňovat jiná kritéria.

Tabulka 2

Přehled výhod a nevýhod jednotlivých př́stupů k výzkumu vizuálií

\begin{tabular}{|c|c|c|c|}
\hline & Expertní hodnocení & Uživatelské hodnocení & Kombinované hodnocení \\
\hline Výhody & $\begin{array}{l}\text { - terminologická } \\
\text { - } \text { ndízké finančnčí } \\
\text { náklady } \\
\text { - rychlost } \\
\text { - lepší možnost } \\
\text { srovnání výsledků } \\
\text { - relativní } \\
\text { univerzálnost }\end{array}$ & $\begin{array}{l}\text { - názor samotných } \\
\text { uživatelů } \\
\text { - vhodný pro zpětnou } \\
\text { vazbu autorům } \\
\text { a nakladatelům } \\
\text { - může odhalovat nové } \\
\text { pole výzkumu } \\
\text { - pozorování práce žáka } \\
\text { s vizuálií }\end{array}$ & $\begin{array}{l}\text { - } \text { větší validita výsledků } \\
\text { i odbor uživatelů } \\
\text { - } \text { komplexnějǔš́ pohled } \\
\text { na výzkumný problém }\end{array}$ \\
\hline Nevýhody & $\begin{array}{l}\text { - chybí názor uživatelů } \\
\text { - předpojatost } \\
\text { výzkumníka } \\
\text { - odlišnosti názorů } \\
\text { odborníků (expertů) }\end{array}$ & $\begin{array}{l}\text { - pečlivá příprava } \\
\text { výzkumu } \\
\text { - správná formulace } \\
\text { otázek } \\
\text { - obtížné sehnat } \\
\text { respondenty } \\
\text { - absence } \\
\text { terminologické } \\
\text { odbornosti ve slovním } \\
\text { hodnocení }\end{array}$ & $\begin{array}{l}\text { - organizační, finanční } \\
\text { a časová náročnost } \\
\text { - rozdílnost pohledů } \\
\text { odborníků a uživatelů }\end{array}$ \\
\hline
\end{tabular}

Zdroj: Autoři.

\subsection{Výzkumy vizuálií z hlediska jejich metodologické orientace}

Kvantitativně orientovaný výzkum je v evaluaci vizuálií využíván podstatně více než další dva přístupy. V rámci expertního hodnocení je jeho základem kvantifikace měřitelných jednotek v učebnici (vizuálií a jejich vlastností). Pokud je tento př́stup použit v rámci uživatelského hodnocení, je osloveno velké množství uživatelů, na kterých je ověřována vhodnost vizuálií zpravidla dotazníkem nebo didaktickým testem. Výsledky jsou pak lépe zobecnitelné. $\mathrm{V}$ rámci výzkumu vizuálií $\mathrm{v}$ učebnicích geografie tento př́ístup převládá ( $60 \% \mathrm{z}$ analyzovaných studií), což může souviset s pozitivistickým myšlením rozšířeným mezi pedagogy i oborovými didaktiky a snahou výsledky numericky vyjádřit. $\mathrm{V}$ neposlední řadě může $\mathrm{k}$ oblibě tohoto př́istupu přispívat 
matematizace věd. Tato orientace výzkumu má klíčový význam především v expertním (65\%) a uživatelském (50 \%) hodnocení.

Naopak kvalitativně orientovaný výzkum je zastoupen podstatně méně než předchozí př́ístup. Jeho podstatou je hlubší proniknutí do problému. Vizuálie jsou expertně hodnoceny zpravidla verbálně (slovně) s uvedením pozitiv a negativ př́slušné vizuálie. Výsledky tak platí pouze pro konkrétní hodnocenou vizuálii a nejsou zpravidla přenositelné na ostatní vizuálie v učebnici. Při využití určitých postupů však částečnou přenositelnost výsledků zajistit lze (Bláha, 2010). U uživatelských hodnocení je nejčastěji používán rozhovor $\mathrm{s}$ žáky nebo učiteli. $V$ rámci naší analýzy byl tento směr výzkumu zjištěn celkem v $25 \%$ studií. Relativně největší oblibu má toto hodnocení u výzkumů uživatelů druhého stupně základních škol (ISCED 2), v rámci nichž tyto výzkumy tvoří přes čtvrtinu všech provedených hodnocení.

Kvalimetrie (nebo tzv. smíšený design výzkumu - kombinace kvantitativně a kvalitativně orientovaných metod) je oproti předchozím př́istupům užívána podstatně méně; pouze v $15 \%$ př́padů z celkového počtu analyzovaných studií. Nižší zastoupení tohoto směru výzkumu je dáno i jeho náročností (finanční, organizační, odbornou, časovou atd.). Na druhou stranu je nutné upozornit, že většina výzkumů využívajících kombinaci expertního a uživatelského hodnocení je založena právě na kvalimetrii. To pravděpodobně souvisí se snahou výzkumníka při analýze vizuálií uplatnit kvantitativní hodnocení (především kategorizaci) a při hodnocení vizuálie uživatelem doplnit výsledky hlubším pohledem na výzkumný problém, tedy užití kvalitativních metod. Srovnání počtu výzkumů v rámci těchto tří orientací ukazuje obrázek 2. 


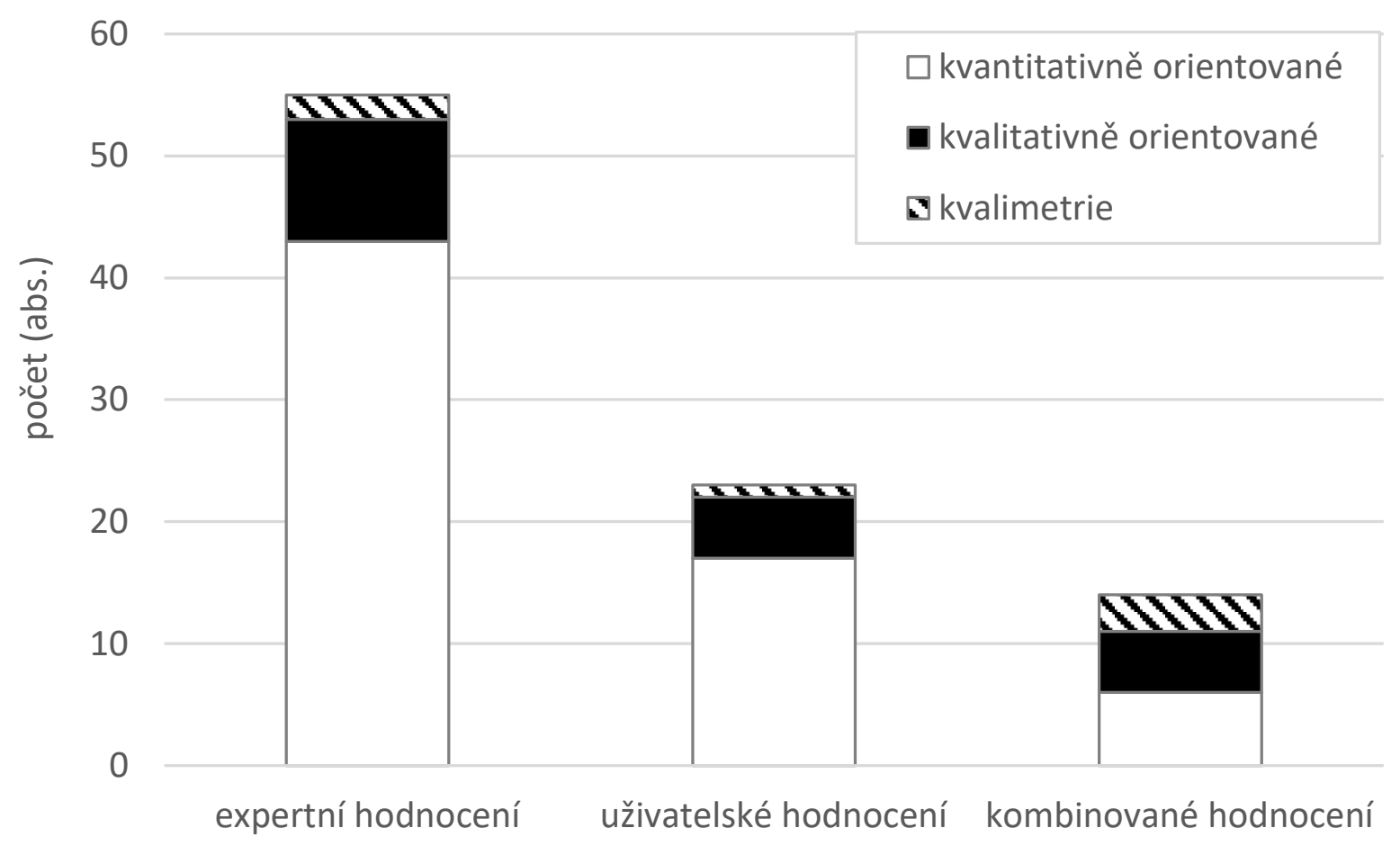

Obrázek 2. Výzkumy $\mathrm{z}$ hlediska participace uživatelů a zastoupení kvantitativně a kvalitativně orientovaných výzkumů v rámci jednotlivých směrů.

\subsection{Výzkumy vizuálií dle konkrétních použitých metod}

Vizuálie lze hodnotit různými metodami. Přehled potenciálních metod výzkumu vizuálií je vhodnou inspirací pro ostatní výzkumníky, kteří koncipují metodiku výzkumu na řešené téma. Na základě analýzy výzkumů učebnic s geografickým obsahem bylo zjištěno, že nejčastěji používanou metodou, celkově i v rámci všech věkových kategorií (mimo ISCED 6 a 7 - viz dále), je kvantitativní obsahová analýza. Především v českých výzkumech je tendencí vizuálie nebo fenomény s nimi související (např typ, funkce, př́tomnost titulků atd.) kategorizovat do skupin na základě jejich společných znaků. Je vcelku logické, že tuto metodu používají pouze odborníci a není tedy užívána v uživatelském hodnocení. Jak ovšem naznačují dosavadní výsledky našeho výzkumu, v rámci rozhovorů s žáky lze zjištovat i jejich představy o kategoriích vizuálií (Trahorsch et al., 2017). Výhodou kvantitativní obsahové analýzy je rychlý sběr dat a pohled na strukturu vizuálií v učebnici. Nejčastěji jsou vizuálie kategorizovány z hlediska jejich typu. Zde je problematická 
nejednotnost kategoriálních systémů (každý autor používá odlišné kategorie), čímž se snižuje možnost komparace výsledků analýz učebnic, a jejich standardizovanost (většinou není zajištěna validita a reliabilita). Ukázky používaných kategoriálních systémů pro typy vizuálií v učebnicích s geografickým obsahem uvádíme v tabulce 3 .

Tabulka 3

Kategorie vizuálií použité v rámci kvantitativní obsahové analýzy z hlediska jejich typu podle vybraných autorů

\begin{tabular}{ll}
\hline Autor & Názvy kategorií vizuálií \\
\hline Wahla (1983) & $\begin{array}{l}\text { kartografické, statistické, obrazové, schematické, geometrické, } \\
\text { znakové }\end{array}$ \\
Metallinos a kol. (1990) & $\begin{array}{l}\text { mapy, tabulky, fotografie, realistické kresby, nákresy } \\
\text { mapy, obrázky, tabulky, grafy, schémata } \\
\text { Paik (1994) }\end{array}$ \\
Slough a kol. (2010) & $\begin{array}{l}\text { fotografie, realistické kresby, stylizovaný nákres, obrazový, schéma (cyklické, sekvenční), průrezy, mapy, tabulky, } \\
\text { diagramy, zvětšeniny, hybridní }\end{array}$ \\
Janko (2012) & $\begin{array}{l}\text { kartografické, kartograficko-statistické, tabulární, obrazové, } \\
\text { schematické, kombinované, ostatní } \\
\text { mapa, tabulka, fotografie, nákres, schéma }\end{array}$ \\
\hline
\end{tabular}

Další metodou, která je velmi často používána, je verbální hodnocení. Základem této metody hodnocení je slovní výčet pozitiv a negativ hodnocené vizuálie (viz např. Janík, 2006; Meijer, 1997). Její nevýhoda tkví v nebezpečí, že hodnotitel může opomenout některé chyby a na druhé straně se zaměřit na nepodstatné vlastnosti vizuálie. $V$ rámci této metody hodnocení pak často dochází $\mathrm{k}$ chybám v hodnocení, které jsou v odborné literatuře často diskutovány; patří mezi ně např́íklad haló efekt, chyba centrální tendence, černobílé vidění, chyba generalizace, efekt dobroty a přísnosti a další (blíže viz Kulka, 2008).

V rámci uživatelského kvantitativního hodnocení jsou nejčastěji užívány dotazníkové metody ( $11 \% \mathrm{z}$ celkového počtu použitých metod) a didaktické testy ( $6 \% \mathrm{z}$ celkového počtu použitých metod). Tyto metody byly užity například ve výzkumech Behnkeové (2014) či Petersona (2016) a slouží pro hromadný sběr dat. Žáci jsou dotazováni na názor na kvalitu vizuálie nebo je u nich měřen výkon vztahující se $\mathrm{k}$ úspěšnosti práce $\mathrm{s}$ vizuáliemi. Relativně nejvíce jsou tyto metody aplikovány u vysokoškolských studentů, což je dáno úrovní jejich kognitivních schopností a tím i nižšími požadavky 
na tvůrce tohoto výzkumného nástroje $\mathrm{z}$ hlediska přiměřenosti položek pro respondenty (u věkové kategorie ISCED 6 a 7 jsou použity tyto metody v polovině výzkumů; nejčastěji doplňují výsledky metod využívajících informační technologie).

V rámci kvalitativního uživatelského hodnocení je nejčastěji využívána metoda rozhovoru ( $9 \% \mathrm{z}$ celkového počtu použitých metod; např. McTigue \& Flowers, 2011). Tato metoda má klíčový význam v hodnocení vizuálií žáky věkové skupiny ISCED 1, protože jejich písemný projev (např. v rámci dotazníku nebo didaktického testu) může být problematický. Naopak u starších žáků tato metoda není využívána vůbec (věková skupina ISCED 3 a starší).

Další, avšak méně často používanou metodou, je kriteriální hodnocení (škálování) na základě předem stanovených kritérií. Kritéria kvality vizuálií však nejsou ve výzkumech jednotná, což ztěžuje komparovatelnost jejich výsledků. Stanovení kritérií jistě přispívá k větší objektivitě výzkumu a využitelnosti výsledků. Přehled stanovených obecných kritérií, které byly užity minimálně ve dvou studiích, ukazuje tabulka 4.

Tabulka 4

Nejčastěji používaná kritéria pro hodnocení kvality vizuálií

\begin{tabular}{ll}
\hline Název kritéria & Výskyt ve výzkumných studiích \\
\hline Atraktivita a zajímavost & $\begin{array}{l}\text { McTigue \& Flowers (2011); Melbo \& Waterman (1936); Metallinos } \\
\text { a kol. (2010); Ysar \& Seremet (2007) }\end{array}$ \\
Čitelnost & Melbo a Waterman (1936); Metallinos a kol. (1990) \\
Souvislost s textem & Štovíčková (2016); Ysar \& Seremet (2007) \\
Umístění a velikost & Červený (2001); Štovíčková (2016); Ysar \& Seemet (2007) \\
Barevné řešení & Červený (2001); Št'ovíčková (2016); Ysar \& Seremet (2007) \\
Správnost titulků & Štovíčková (2016); Ysar \& Seremet (2007) \\
Přehlednost & Červený (2001); Metallinos a kol. (1990); Tang (1994) \\
\hline
\end{tabular}

Poněkud specifickými metodami hodnocení vizuálií jsou metody využívající informační technologie. Lze předpokládat, že v souvislosti s růstem významu těchto technologií ve společnosti bude růst jejich význam i v této oblasti výzkumu. Nejčastěji je užíváno metody eye-trackingu, která je založena na snímání pohybu oka (zornice); pomocí dráhy pohybu zornice oka je možné určit, na na které prvky učebnice (např. výkladový text, nadpis atd.) či vizuálie zaměřuje žák svou pozornost, a využívá je tak při učení či získávání nových informací, a kterou část učebnice nebo vizuálie naopak nevyužívá (Behnke, 2014). Nejvíce je této metody využíváno u výzkumů středoškolských a vysokoškolských studentů. 
Další, méně často používané metody, jsou pozorování práce uživatelů s vizuáliemi a experiment (viz např. Mason, Pluchino, \& Tornatora, 2015). Právě u experimentu je poněkud zarážející, že není ve výzkumech didaktiky geografie používán ve větší míře, jelikož je vnímán jako progresivní a odhaluje hlubší kauzality (Gavora, 2008); naopak v pedagogické psychologii je tato metoda velmi rozšířena a poskytuje základní poznatky o fungování percepce vizuální informace (viz např. Lewalter, 2003). Je pravděpodobné, že absence experimentu ve výzkumech vizuálií je spojena zejména s časovou a organizační náročností. Celkové výsledky analýzy výzkumů z hlediska použitých metod hodnocení vizuálií ukazuje tabulka 5.

Tabulka 5

Použité metody v rámci výzkumu vizuálií učebnic s geografickým obsahem

\begin{tabular}{cc}
\hline Použitá metoda & Počet (abs.) \\
\hline kvantitativní obsahová analýza & 53 \\
verbální hodnocení & 30 \\
dotazník & 15 \\
rozhovor & 13 \\
kriteriální hodnocení (škálování) & 11 \\
didaktický test & 9 \\
informační technologie & 6 \\
pozorování & 3 \\
experiment & 3 \\
\hline
\end{tabular}

\subsection{Komparace zaměření českých a zahraničních výzkumů vizuálií}

České a zahraniční výzkumy vizuálií v učebnicích geografie vykazují podobné tendence. Typickým rysem je snaha tyto strukturní prvky kategorizovat na základě společných znaků. $\mathrm{V}$ zahraničních výzkumech jsou kategoriální systémy velmi dobře ukotveny $\mathrm{v}$ teorii pedagogické a kognitivní psychologie (např. Slough et al., 2010, kategoriální systém uplatněný v jejich studii vychází z teorie psychodidaktických funkcí vizuálií, resp. z teorie multimediálního učení). Naopak kategoriální systémy u českých autorů vznikají postupným zpřesňováním a ověřováním (srov. Janko, 2012; Wahla, 1983).

V zahraničních výzkumech je typickým rysem zkoumání vztahů mezi výkladovým textem a samotnými vizuáliemi. Pozornost je zaměřena na souvislosti v obsahu (Ysar \& Seremet, 2007), na problematiku integrace textu a vizuálií (Peterson, 2016). Výsledky studií ukazují na větší přínosy v procesu učení při 
souladu (souvislosti) a integraci textu a vizuálií. Naopak v rámci tuzemských výzkumů učebnic je zřejmý pohled na jednotlivé strukturní komponenty učebnice odděleně s minimální pozorností na vztahy a vazby mezi textem a vizuáliemi, popř. dalšími komponenty učebnice (srov. Dobrylovský, 2009; Janko, 2015; Janoušková, 2009; Knecht \& Lokajíčková, 2013; Pluskal, 1989). Učebnice, jak vyplývá z definice a jejího vymezení, je systémem, což znamená, že jednotlivé složky a prvky musí být ve vzájemných vztazích. Také tyto vztahy (např. text-vizuálie, vizuálie-učební úlohy apod.) by měly být předmětem výzkumu.

České výzkumné prostředí je zaměřeno na užití relativně úzkého spektra výzkumných metod. $V$ rámci výzkumů dochází zřídka k jejich kombinaci, což by jistě poskytlo validnější výsledky. Poněkud překvapivým rysem je v rámci tuzemských výzkumů absence analýzy vývoje vizuálií v učebnicích zeměpisu (geografie) v posledních dekádách. V zahraničních analýzách výsledky ukazují, že tematické i obsahové zaměření vizuálií se v posledních sto letech zásadně změnilo nejen díky technologickým možnostem tisku, ale především $\mathrm{v}$ důsledku rychlých změn paradigmat v geografii (Walford, 1995). V rámci tuzemských výzkumů chybí i tematická analýza vizuálií v rámci jednotlivých dílčích subdisciplín geografie (např. regionální, socio-ekonomická část atd.), čemuž je v rámci zahraničních analýz rovněž věnována pozornost (Jennkins, 2006; Wright, 1979; Ysar \& Seremet, 2007 a další).

\subsection{Vybrané výsledky výzkumu vizuálií v učebnicích s geografickým obsahem a jeho dalši perspektivy}

V rámci provedené analýzy výzkumu vizuálií byly posouzeny i jeho perspektivy a vybrané výsledky, které mají potenciál pro další výzkum. Výběr prezentovaných výsledků reflektuje především srovnání českých a zahraničních učebnic a srovnání struktury a postavení vizuálií v jednotlivých učebnicích. Dle uvedených výsledků lze potom identifikovat jiné přístupy ke koncepci učebnic s geografickým obsahem, než je tomu u tuzemských učebnic.

Zásadním rozdílem mezi českými a zahraničními učebnicemi geografie (především těmi, které byly předmětem výzkumů jiných autorů) je variabilita v počtu a podílu vizuálií. Tuzemské učebnice se podle dosavadních výsledků vždy vyznačovaly nevyrovnaným podílem jednotlivých typů vizuálií, klíčový význam měly vždy fotografie (Janko, 2015; Wahla, 1983); naopak zahraniční 
učebnice se vyznačují relativně vyrovnanějším podílem jednotlivých typů vizuálií (Metallinos et al., 1990; Paik, 1994).

Vývoj počtu a podílu vizuálií a jejich typů vykazuje v souvislosti s rostoucím věkem uživatelů učebnic zajímavé výsledky. Klíčová je především tendence snižování počtu vizuálií na úkor textu a snižování podílu fotografií ve prospěch zvyšování podílu abstraktních a kvantitativních vizuálií, především map, grafů a diagramů (Christner \& Kleier, 2011; Kučerová et al., 2014). Tato tendence může být způsobena předpokladem pedagogických psychologů o postupném rozvoji abstraktního myšlení u žáků (např. Baican, 2007; Kohoutek, 2008). Na druhou stranu je nutné upozornit na výsledky předešlých výzkumů, které uvádějí, že mladší žáci již mají vyvinuté předpoklady pro pochopení symboliky znaků, tudíž je vhodné rozvíjet již od začátku školní docházky jejich vizuoprostorový aspekt inteligence a zařazovat do jejich činností i práci s abstraktními vizuáliemi (Balchin, 1976; Pupala \& Mašková, 1997).

Poněkud překvapujícím výsledkem, na němž se shoduje většina českých i zahraničních výzkumů, je absence většího množství map jako základního vyjadřovacího a zároveň didaktického prostředku geografie (Wedden, 1997). Např́íklad Janko (2015), Štovíčková (2016) i Wahla (1983) udávají podíl map, plánů a mapových nákresů na celkovém počtu vizuálií v českých učebnicích geografie pouze mezi 5-13\%.V zahraničních učebnicích je jejich podíl poněkud větší, přesto velmi nízký; pokud vezmeme v úvahu pouze učebnice pro základní školy, pohybuje se podíl map ve výsledcích nám dostupných výzkumů v rozsahu 3-20 \% (Fedotova et al., 2014; Janko, 2015; Metallinos et al., 1990; Slough et al., 2010). Tyto výsledky ale mohou být způsobeny i používáním atlasů jako jedněch z nejdůležitějších didaktických prostředků geografie (Pettersson, 1991); z tohoto hlediska není vhodné mapy v těchto dvou didaktických prostředcích dublovat, nýbrž by se měly vzájemně doplňovat. To by ovšem vyžadovalo větší spolupráci nakladatelství učebnic i atlasů, což se bohužel vzhledem k privátnímu charakteru procesu vzniku atlasů a učebnic daří prozatím s velkými obtížemi.

Samotní uživatelé v rámci uživatelského hodnocení vnímají u vizuálií především jejich motivační funkci. Na základě dalších zjištění jim většinou ve školní výuce nepřisuzují informační funkci a snadno zaměňují jejich estetickou a užitnou funkci. Pokud se jim vizuálie líbí, využívají ji rovněž jako zdroj 
informací, protože z jejich pohledu vizuálie není obtížným zdrojem k získávání informací (McTigue \& Flowers, 2011; Trahorsch et al., 2017).

Problematická je absence hodnocení kvality vizuálií, především z hlediska jejich použitelnosti. V rámci výzkumů se klade důraz na analýzu učebnic jako celku, nejsou však, až na výjimky (např. Janík, 2006), vybrány reprezentativní vizuálie, které by byly hodnoceny podle předem stanovených kritérií.

V rámci českých výzkumů je problematická absence většího množství výzkumů učebnic s geografickým obsahem pro první stupeň základních škol (především učebnic vlastivědy). Přesto některé výzkumy ukazují na potřebu tyto učebnice zkoumat; například Šimeková (1993) zjistila, že didaktická vybavenost ${ }^{5}$ učebnic vlastivědy je na mnohem nižšś úrovni než u učebnic zeměpisu pro druhý stupeň základních škol.

\section{Závěr}

Tato přehledová studie je analýzou výzkumů vizuálních prvků v učebnicích s geografickým obsahem. Tyto didaktické prostředky mají svá specifika (především prostorovost), což vyznačuje specifické postavení vizuálií.

Přehled výzkumů ukazuje na značné rezervy v oblasti uživatelského hodnocení, kvalitativně orientovaných výzkumů a výzkumu vizuálií v učebnicích pro první stupeň základních škol. Tato přehlížená zaměření výzkumu mohou být vhodnou inspirací pro všechny výzkumníky. Problematické je využívání úzkého spektra tzv. tradičních metod; využívání méně tradičních výzkumných metod by mohlo $\mathrm{v}$ budoucnu odhalit nová výzkumná pole a také by mohlo pomoci vyřešit nedostatečně objasněné otázky učení z obrazového materiálu. Mezi tyto metody mohou patřit didaktické testy, které zjištují úspěšnost práce s vizuáliemi, a tím i efektivitu učení, či metody škálování a sémantického diferenciálu v uživatelském hodnocení, čímž lze zjistit vztah žáků k vizuálii a výsledky zároveň kvantitativně zpracovat.

Limitem předkládané studie je samozřejmě výběr analyzovaných studií. I přes snahu autorů stanovit objektivní kritéria výběru studií (vyhledávání v databázích, klíčová slova, kritéria pro vyřazení studií z analýzy) je možné, že některé studie autorům unikly. Přesto se autoři domnívají, že

Metodika měření didaktické vybavenosti je kvantitativně orientované měření kompletnosti struktury učebnice. Její výsledky poskytují přehled o rozsahu využití strukturních komponentů učebnice (Průcha, 1998). 
celkový charakter a tendence prezentovaných výsledků by zůstaly nezměněny. Předkládaná studie analyzuje pouze některá kritéria metodologických aspektů analyzovaných studií; je možné, že jiní autoři by volili jiná kritéria analýzy či výběr klíčových výsledků studií.

Ačkoliv se v průběhu 20. století množství vizuálií v učebnicích s geografickým obsahem zásadně zvýšilo, výzkumy zabývající se touto problematikou tak četné nejsou. Zaměření na tento didaktický prostředek $\mathrm{s}$ vysokým edukačním potenciálem, který ale podle výsledků dostupných výzkumů není plně uplatňován, by tedy nemělo být opomíjeno. V následujícím období lze očekávat růst významu vizuálií v učebnicích prakticky všech vyučovacích předmětů. Dále bude jistě narůstat i význam elektronických (digitálních) učebnic a e-learningu, m-learningu i u-learningu, v rámci nichž se otevírá další didaktické uplatnění jiných typů vizuálií (např. animace, videa, interaktivní vizuálie). Také z toho důvodu je hodnocení tohoto strukturního komponentu učebnic nutností a vyplývá z požadavků společnosti. Většina předchozích výzkumů využívala pouze omezený počet výzkumných metod; jejich vhodná kombinace a zapojení expertů i uživatelů do výzkumu dávají cenné výsledky, které mohou poskytnout mimořádně cennou zpětnou vazbu autorům učebnic a mohou přispět $\mathrm{k}$ vyšší efektivitě učení uživatelů. Hodnocení vizuálií $\mathrm{v}$ učebnicích z hlediska jejich použitelnosti může pomoci odhalit chyby v jejich návrhu a provedení, které mohou mít vliv na vznik miskoncepcí.

\section{Literatura}

Baican, V. (2007). Size and sum of the cartographic representations from the Romanian cartographic school manuals after 1989. Analele Stiintifice ale Universitatii, 53(2), 191-194.

Balchin, W. G. V. (1976). Graphicacy. The American Cartographer, 3(1), 33-38.

Bednařík, M. (1981). Problematika informační struktury učebnice fyziky. Acta Univ. Palackianae Olomucensis, 69(2), 225-241.

Behnke, Y. (2014). Visual qualities of future geography textbook. European Journal of Geography, 5(4), 56-66.

Bláha, J. D. (2010). Various ways of assessment of cartographic works. In G. Gartner \& F. Ortag (Eds.), Cartography in Central and Eastern Europe (s. 211-231). New York: Springer.

Carney, R. N., \& Levin, J. R. (2002). Pictorial illustrations still improve students' learning from text. Educational Psychology Review, 14(1), 5-26.

Červený, P. (2001). Hodnocení kartografických výstupů v učebnicích zeměpisu a geografie pro základní a střední školy. In K. Jedlička \& V. Čada (Eds.), 14. kartografická konference. Plzeň: Západočeská univerzita. Dostupné z http://old.gis.zcu.cz/kartografie/konference2001/ sbornik/cerveny/Cerveny_referat.htm 
Dobrylovský, J. (2009). Dlouhodobé trendy ve vývoji obsahu učebnic zeměpisu pro gymnázia. E-Pedagogium, 8(5), 7-25.

Đukičin, S., Ivanović-Bibić, L., Lukić, T., \& Dubovina, Z. (2014). Analysis of the utilization of supplementary illustrations: An example of the selected teaching units from the fifth grade geography textbook (Republic of Serbia). Geographica Pannonica, 18(4), 29-95.

Fedotova, O., Latun, V., \& Okuneva, I. (2014). Visual image of the continent in Russian textbooks on geography (1825-2013). Procedia - Social and Behavioral Sciences, 14(5), 731-737.

Gavora, P. (2008). Úvod do pedagogického výskumu. Bratislava: Vydavatel'stvo UK.

Gregory, D., Johnston, R., Pratt, G., Watts, M., \& Whatmore, S. (Eds.). (2009). The dictionary of human geography. Malden: Blackwell.

Hendl, J. (2012). Kvalitativní výzkum. Praha: Portál.

Christner, L., \& Kleier, C. (2011). Quantitative reasoning in introductory environmental science textbooks. Journal of Environmental Studies and Sciences, 1(4), 296-300.

Janík, T. (2006). Teorie konceptuální změny učebnice. In J. Maňák \& D. Klapko (Eds.), Učebnice pod lupou (s. 33-44). Brno: Paido.

Janko, T. (2012). Nonverbální prvky v učebnicích zeměpisu jako nástroj didaktické transformace. Brno: Masarykova univerzita.

Janko, T. (2015). Srovnávací analýza typů nonverbálních prvků v současných českých a německých učebnicích školní geografie. Pedagogická orientace, 25(2), 225-248.

Janoušková, E. (2009). Vztah úrovně didaktické vybavenosti a míry obtížnosti textu současných učebnic. Pedagogická orientace, 19(1), 56-72.

Jennkins, S. A. (2006). A content comparison of six physical geography textbooks spanning a century. International Research in Geographical and Environmental Education, 15(1), $1-14$.

Knecht, P., \& Lokajíčková, V. (2013). Učební úlohy jako příležitosti k rozvíjení a dosahování očekávaných výstupů: analýza koherence učebnic a RVP ZV. Pedagogika, 64(2), 167-181.

Kohoutek, R. (2008). Kognitivní vývoj dětí a školní vzdělávání. Pedagogická orientace, 18(3), $3-22$.

Kučerová, S. R., Novotná, K., Hátle, J., \& Bláha, J. D. (2014). Geographical names frequency map as a tool for the assessment of territorial representations in geography textbooks. In P. Knecht, E. Matthes, S. Schütze, \& B. Aamotsbakken (Eds.), Methodologie und Methoden der Schulbuch-und Lehrmittelforschung (s. 264-278). Bad Heilbrunn: Klinkhardt.

Kulka, J. (2008). Psychologie umění. Praha: Grada.

Lewalter, D. (2003). Cognitive strategies for learning from static and dynamic visuals. Learning and Instruction, 13(2), 177-189.

Macek, Z. (1984). Obraz jako didaktický prostředek Pedagogika, 34(4), 453-469.

Mareš, J. (1995). Učení z obrazového materiálu. Pedagogika, 45(4), 318-327.

Mareš, J. (2002). Pedagogicko-psychologický výzkum založený na obrazovém materiálu. Československá psychologie, 46(2), 120-137.

Mason, L., Pluchino, P., \& Tornatora, M. C. (2015). Eye-movement modeling of integrative reading of an illustrated text: Effects on processing and leasing. Contemporary Educational Psychology, 41(1), 172-187.

McTigue, E. M., \& Flowers, A. C. (2011). Science visual literacy: Learners' perceptions and knowledge of diagrams. The Reading Teacher, 64(8), 578-589. 
Meijer, H. (1997). Images of Netherlands. Tijdschrift voor economische en sociale geografie, 88(1), 85-90.

Melbo, I. R., \& Waterman, I. R. (1936). Pictures in geography textbooks. The Elementary School Journal, 36(5), 362-376.

Metallinos, N., Muffoletto, R., Petterson, R., Shaw, J., \& Takakuwa, Y. (1990). The use of verbovisual information in textbooks - a cross-cultural experience. London: University of London.

Paik, H. (1994). A comparative study of the map content included in junior high school world geography textbooks and school atlases in USA and Korea (Disertační práce). Pittsburgh: University of Pittsburgh.

Paivio, A. (2014). Mind and its evolution: A dual coding theoretical approach. New York: Psychology Press.

Peeck, J. (1993). Increasing picture effects in learning from illustrated text. Learning and Instruction, 3(1), 227-238.

Pešková, K. (2012). Vizuální prostředky pro výuku reálií: výsledky analýzy učebnic němčiny. Pedagogická orientace, 22(2), 243-265.

Peterson, M. O. (2016). Schemes for integrating text and image in the science textbook: Effects on comprehension and situational interest. International Journal of Environmental \& Science Education, 11(6), 1365-1385.

Pettersson R. (1991). The use of verbo-visual information in the teaching of geography: Views from teachers. Washington: International Visual Literacy Association.

Pluskal, M. (1989). Hodnocení kvality textu učebnic zeměpisu. Sborník ČSGS, 94(4), 285-292.

Průcha, J. (1998). Učebnice: teorie a analýzy edukačního média. Brno: Paido.

Průcha, J. (2006). Učebnice: teorie, výzkum a potřeby praxe. In J. Maňák \& D. Klapko (Eds.), Učebnice pod lupou (s. 9-23). Brno: Paido.

Průcha, J. (2008). Možnosti výzkumu učebnic ve vztahu k učení. In P. Knecht \& T. Janík (Eds.), Učebnice z pohledu pedagogického výzkumu (s. 28-36). Brno: Paido.

Pupala, B., \& Mašková, M. (1997). Slovensko na mapách detí: detská naivná kartografia. Pedagogika, 48(4), 317-328.

Pýchová, I. (1990). K funkci vizuálií v rozvoji osobnosti žáka. Pedagogika, 40(6), 669-684.

Řezníčková, D. (2014). Didaktika geografie: proměny identity oboru. In I. Stuchlíková \& T. Janík, et al. (Eds.), Oborové didaktiky: vývoj - stav-perspektivy (s. 259-288). Brno: MU.

Slough, S. W., McTigue, E. M., Kim, S., \& Jennings, S. K. (2010). Science textbooks use of graphical representation. Reading Psychology, 31(3), 301-325.

Spousta, V. (2007). Vizualizace. Brno: Masarykova univerzita.

Šimeková, J. (1993). Hodnotenie rukopisu Stanko a kol.: vlastivěda pre 3. roč. ZŠ. Technológia vzdelávania, 1(2), 10-11.

Št’ovíčková, I. (2016). Postavení a obsahová vybavenost fyzické geografie v současných českých učebnicích zeměpisu pro základní školy a nižší stupně gymnázií (Diplomová práce). Praha: Univerzita Karlova v Praze.

Tang, G. M. (1994). Textbook illustrations: A cross-cultural study and its implications for teachers of language minority students. The Journal of Educational Issues of Language Minority Students, 13(2), 175-194.

Trahorsch, P., Kučerová, S. R., Bláha, J. D., Knecht, P., \& Janko T. (2017). Hodnocení geografických vizuálií žáky základních škol: pilotní studie. In S. Michek, J. Vondroušová, \& J. Vítová (Eds.), 
Vliv technologií v oblasti vzdělávání a v pedagogickém výzkumu (s. 114-116). Hradec Králové: Gaudeamus.

UNESCO Institute for Statistics (2012). International standard classification of education: ISCED 2011. Montreal: UNESCO Institute for Statistics.

Veriki, I. (2002). What is the value of graphical displays in learning? Educational Psychology Review, 14(3), 261-312.

Voženílek, V., Kaňok, J., Bláha, D., Dobešová, Z., Hudeček, T., Kozáková, M., \& Němcová, Z. (2011). Metody tematické kartografie. Olomouc: Univerzita Palackého v Olomouci.

Wahla, A. (1983). Strukturní složky učebnic geografie. Praha: SPN.

Walford, R. (1995). Geographical textbooks 1930-1990. Paradigm, 1(18), 1-12.

Wedden, P. (1997). Learning through maps. In M. Williams \& D. Tilbury (Eds.), Teaching and learning geography (s. 168-179). New York: Routledge.

Wright, D. R. (1979). Visual images in geography texts: The case of Africa. Geography, 64(3), 205-210.

Ysar, O., \& Seremet, M. (2007). A comparative analysis regarding pictures included in secondary school geography textbooks taught in Turkey. International Research in Geographical and Environmental Education, 16(2), 157-187.

\section{Autoři}

Mgr. et Mgr. Petr Trahorsch, Univerzita J. E. Purkyně v Ústí nad Labem, Pedagogická fakulta, Katedra preprimárního a primárního vzdělávání, Hoření 13, 40096 Ústí nad Labem, e-mail: petr.trahorsch@seznam.cz

PhDr. RNDr. Jan D. Bláha, Ph.D., Univerzita J. E. Purkyně v Ústí nad Labem, Přírodovědecká fakulta, Katedra geografie, České mládeže 8, 40096 Ústí nad Labem, e-mail: jd@jackdaniel.cz

Mgr. Tomáš Janko, Ph.D., Masarykova univerzita, Pedagogická fakulta, Institut výzkumu školního vzdělávání, Poříčí 31, 60300 Brno, e-mail: janko@ped.muni.cz

\section{Research on visuals in geography textbooks: A review}

Abstract: The article is a review study. Its aim is to define and critically evaluate the methodological approaches of visual research in geography textbooks. Another aim of this study is to summarize the main conclusions of selected studies. There is a clear terminological inconsistency in naming the visual component of textbooks. Altogether 92 studies in Czech and English were analysed without time and territory specifications. Multidisciplinary full-text databases (EBSCO, WoS, SCOPUS, ERIC, ProQuest and Geobibline) were searched using a combination of keywords in Czech and English language. The analysis of the research shows that the expert assessments prevail in the research using predominantly quantitative methods, especially quantitative content analysis of visuals; a questionnaire and a didactic test are of 
major importance in the quantitative user assessment have questionnaire and the didactic test. In addition, unequal distribution of visually-oriented research textbook across age groups was found; a neglected area of research is assessment or analysis of textbooks for the ISCED 1 age group. According to the results of the analysed studies, photographs are the most important visuals in geography textbooks; although the map is one of the typical geographical visual, its share on the total number of visuals in textbooks is relatively low.

Keywords: visuals, geography textbook, homeland study textbook, textbook with geographic content, review study

Hasman, J., Kostelecká, Y., \& Hána, D. (2017). Integrace žáků-cizinců v širším kontextu. Praha: Univerzita Karlova.

Paralelně s růstem počtu imigrantů, pestrostí jejich národnostního a etnického složení a počtem států zasažených migrací roste i význam studia této problematiky. Tradičně se jí zabývali zejména sociální geografové, jejichž př́istupy jsou do značné míry unikátní, když se věnují zejména jeho prostorovým aspektům a podmíněnostem na různých hierarchických úrovních. Přitom prostorovost tohoto jevu je nejen zásadní pro jeho pochopení, ale je také jedním z jeho nejšířeji vnímaných znaků. Důležitou roli by však měli sehrát a do řešení problematiky se více zapojit také 10 výzkumníci v oboru pedagogiky a psychologie, kteří by měli svou odbornou profilací promlouvat do diskuze ke stále rostoucímu významu integrace dětí imigrantů do hostitelských společností prostř̌ednictvím místního školství. Primární motivací k sepsání této publikace je proto představení geografických přístupů ke studiu migrace české pedagogické odborné veřejnosti, pro kterou by mělo být seznámení s tématy prostorových souvislostí migrace a integrace cizinců přínosné pro rozšriření jejich dosavadních odborných zkušeností. 